RESEARCH ARTICLE

\title{
Application of pyraclostrobin as an alternative to reduce phytotoxification of fomesafen in common bean
}

\author{
Jaqueline Schmitt ${ }^{1 *}$, Wilian Jochem ${ }^{1}$, Guilherme Romani de Mello ${ }^{2}$, Juliano José Schiessel ${ }^{1}$, Samyra \\ Coratto Demartini ${ }^{1}$, Samuel Luiz Fioreze ${ }^{1}$, Antonio Mendes de Oliveira Neto ${ }^{2}$ and Naiara Guerra $^{1}$
}

${ }^{1}$ Federal University of Santa Catarina, Curitibanos, SC, Brazil.

${ }^{2}$ Santa Catarina State University, Lages, SC, Brazil.

*Author for correspondence: schmitt.jaque@gmail.com

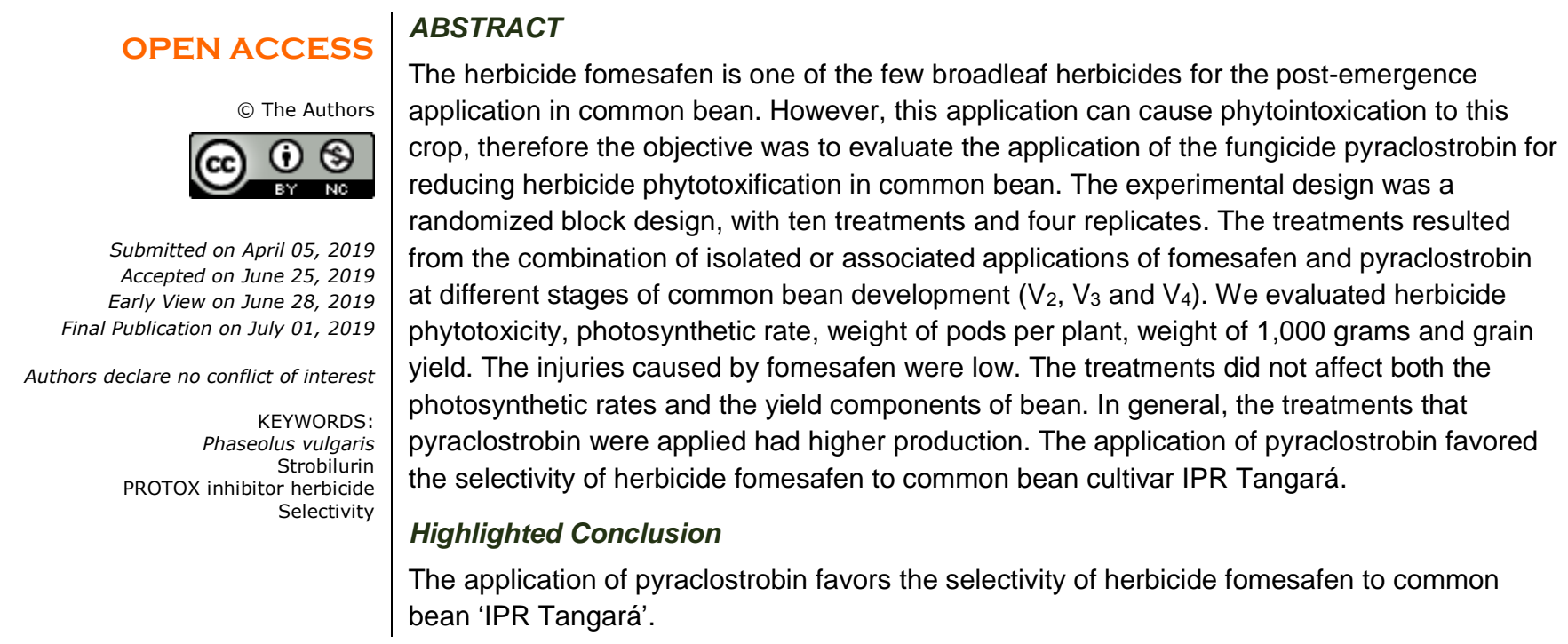

\section{INTRODUCTION}

One of the main difficulties for common bean production is due to weed interference (Galon et al. 2018), since this shows a low competitive capacity, because it is a plant with reduced ability to shade the soil in the first stages of development. Moreover, its root system is poorly developed and the crop presents a short cycle, making the weed infestation privileged, interfering in the crop and impeding the maximum productive potential from being reached (Cury et al. 2011; Manabe et al. 2014; Galon et al. 2016).

According to Kozlowski et al. (2002), the critical period of prevention of weed interference for common bean crop occurs between the V4 to R6 stages. That is, in order to achieve maximum productivity, it is necessary that the crop be free of weeds during this period. The main method of weed management is chemical control, since it is efficient, practical and economical, being the most used in Brazil. However, the bean crop is sensitive to some herbicides and the level of phytotoxification depends on several factors, among which the following stand out: the cultivar, the herbicide, the climate, the dose and the stage of development of the crop at the moment of application (Takano et al. 2015).

The herbicide fomesafen is one of the few latifolicides registered for common bean applied in post emergence (Silva et al. 2013). Characterized as susceptible an inhibitor of the protoporphyrinogen oxidase (PROTOX) enzyme, take the sucetible plants to death due to oxidative stress, resulting from the formation of reactive oxygen species (ROS) (Alves et al. 2018). Studies show that the application of this herbicide alone or associated with other pesticides can cause phytotoxification to the crop. Having as a consequence of this injuries such as chlorosis and necrosis foliar, flowering delay, enlargemente of the cycle period, and productivity reduction (Linhares et al. 2014; Takano et al. 2015).

In the last years, beneficial physiological effects have been studied for plants that are treated with strobilurin fungicides. In this group of fungicides there is a broad-spectrum molecule, which controls the major fungal diseases 
of bean culture, the pyraclostrobin. This molecule increases the photosynthetic rate and activity of the enzyme nitrate reductase, decreases the mitochondrial respiratory rate and reduces oxidative stress in plants. In addition, there is an increase in the assimilation rate of $\mathrm{CO}_{2}$, number of pods, mass of 1000 grains, protein content and the final yield (Fagan et al. 2010; Machado et al. 2018).

Knowing that one of the effects promoted by pyraclostrobin in the plant is to decrease oxidative stress, and that the mechanism of action of fomesafen results in an increase in the formation of ROS, it is assumed that the application of pyraclostrobin could prevent or reduce the formation of ROS after application of fomesafen, avoiding the occurrence of chlorosis and necrosis symptoms, besides deleterious effects on growth and productivity.

The hypothesis of the work was that the damages caused by the herbicide fomesafen in the common bean could be reduced with the application of the fungicide pyraclostrobin. Thus, the objective of the present work was to evaluate if the application of the fungicide pyraclostrobin would be beneficial to the selectivity of fomesafen to the common bean.

\section{MATERIAL AND METHODS}

The experiment was implemented on November 21, 2016, in the city of Curitibanos, State of Santa Catarina, Brazil. The soil of the area is classified as Cambissolo Háplico with a slightly wavy topography and good drainage (Embrapa 2018). It consists of $760 \mathrm{~g} \mathrm{~kg}^{-1}$ clay, $110 \mathrm{~g} \mathrm{~kg}^{-1}$ silt, $130 \mathrm{~g} \mathrm{~kg}^{-1}$ sand, $24.00 \mathrm{~g} \mathrm{dm}^{-3}$ organic matter and pH $\left(\mathrm{CaCl}_{2}\right)$ of 4.94 (layer analysis of $0-20 \mathrm{~cm}$ of depth). The climate of the region is classified according to Köppen (1948) as cfb - humid subtropical climate. The climatic conditions (precipitation, radiation, minimum, maximum and average temperature) during the period of conduction of the experiment are presented in Figure 1.
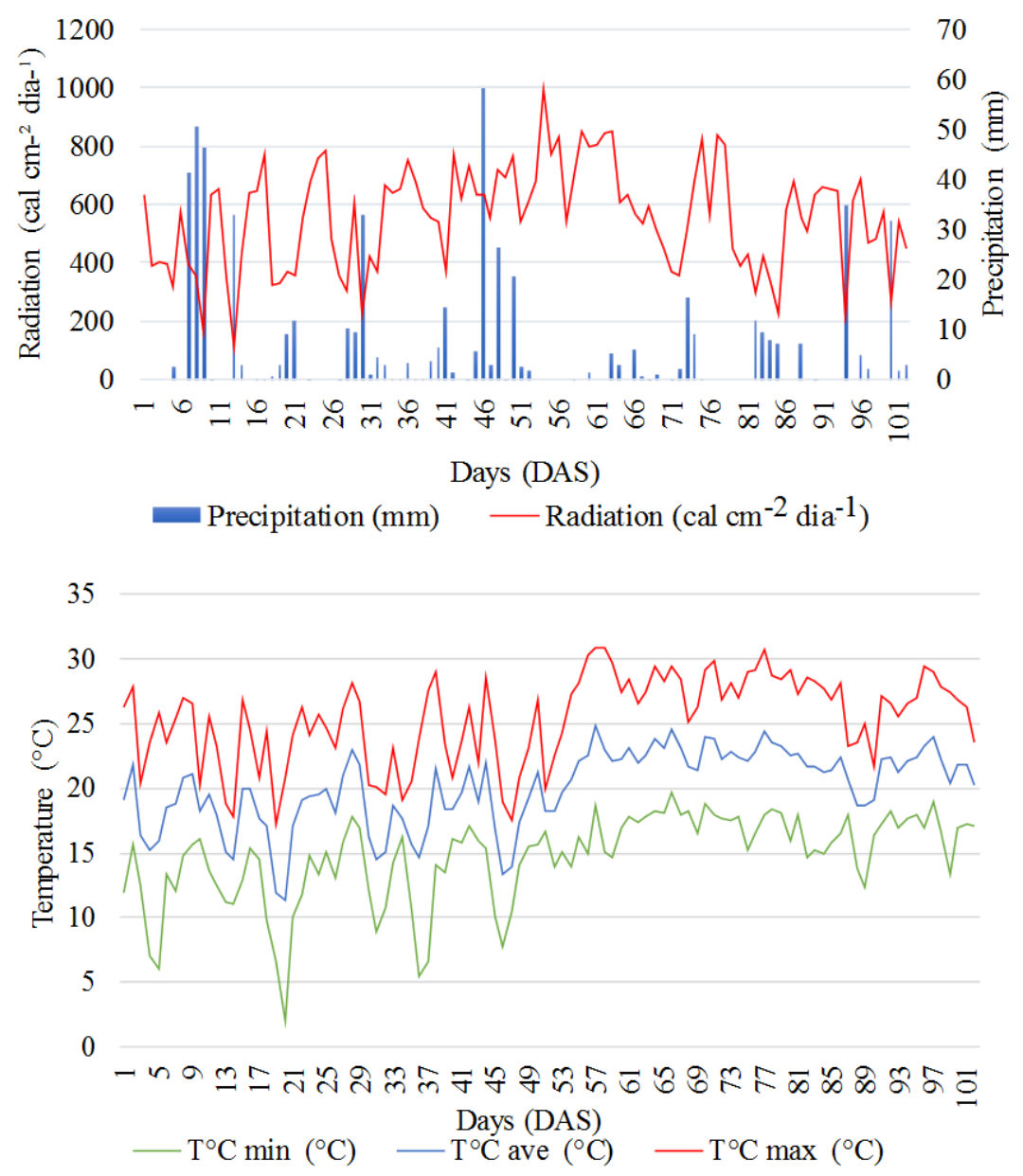

Figure 1. Precipitation, average daily radiation and minimum, average and maximum temperature during the cycle of the bean.

The cultivation was in no-tillage system, with the anticipated burndown, at 20 days before sowing, using the herbicides, tepraloxydim $100 \mathrm{~g} \mathrm{ha}^{-1}$ (Aramo 20 ${ }^{\circledR}$ ), 2.4-D $806 \mathrm{~g} \mathrm{ha}^{-1}$ (DMA $806 \mathrm{BR}^{\circledR}$ ) and glyphosate $720 \mathrm{~g} \mathrm{ha}^{-1}$ (Roundup Original ${ }^{\circledR}$ ). A John Deere ${ }^{\circledR}$ tractor model 5085E and a Vence Tudo ${ }^{\circledR}$ seeder-fertilizer model AS 11500 were used for sowing. 
The experiment was conducted free of weeds, being realized in pre-emergency one application of paraquat 400 $\mathrm{g} \mathrm{ha}^{-1}$ of active ingredient (Gramoxone $\left.200^{\circledR}\right)$ with the Agral $^{\circledR}$ adjuvant $\left(0.2 \% \mathrm{v} \mathrm{v}^{-1}\right)$ in total area after bean sowing, weeding was performed, after new weed emergence flows (when weeds had four leaves) and before the canopy closure of the crop. The free weed experiment was conducted to isolate the effect of the treatments of possible weed interference.

The fertilization was made first in the base with $200 \mathrm{~kg} \mathrm{ha}^{-1}$ of $09-33-12$ and the complement with a coverage fertilization with $70 \mathrm{~kg} \mathrm{ha}^{-1}$ of potassium chloride $(60 \% \mathrm{~K})$ and $150 \mathrm{~kg} \mathrm{ha}^{-1}$ of urea $(45 \% \mathrm{~N})$, realized on V2 stage.

The cultivar used was IPR Tangará, cultivar of the carioca commercial group (White bean), undetermined, type II and with a mean cycle of 87 days (IAPAR 2019). Seeds were treated before sowing with pyraclostrobin + methyl thiophanate + fipronil (Standak Top $^{\circledR}$ at a dose of $200 \mathrm{~mL} 100 \mathrm{~kg}$ of seed-1).

The experimental design was a randomized block with ten treatments and four replications. Each experimental unit consisted of 5 lines of $3.00 \mathrm{~m}$ of length, spaced at $0.40 \mathrm{~m}$ between rows and seeding density of 12 seeds per linear meter. The plot area was composed of the three central lines, and the $0.50 \mathrm{~m}$ border was removed from the ends of each line.

The treatments resulted from the combination of isolated or associated applications (sequential applications or tank mix) of fomesafen and pyraclostrobin at different stages of common bean development (V2, V3 and V4), according to Table 1.

Table 1. Treatments used to evaluate the selectivity of fomesafen and pyraclostrobin combinations in the crop of IPR Tangará.

\begin{tabular}{|c|c|}
\hline Treatments & Product - Application Phenological Stages \\
\hline 1 & Control \\
\hline 2 & Fomesafen $(\mathrm{FOM})-\mathrm{V}_{3}{ }^{*}$ \\
\hline 3 & Pyraclostrobin (PIR) $-V_{3}$ \\
\hline 4 & $\mathrm{PIR} / \mathrm{PIR}-\mathrm{V}_{2} / \mathrm{V}_{4}$ \\
\hline 5 & $\mathrm{PIR} / \mathrm{FOM}-\mathrm{V}_{2} / \mathrm{V}_{3}{ }^{*}$ \\
\hline 6 & $\mathrm{PIR}+\mathrm{FOM}-\mathrm{V}_{3}{ }^{*}$ \\
\hline 7 & $\mathrm{PIR} / \mathrm{FOM}-\mathrm{V}_{3}{ }^{*}$ \\
\hline 8 & $\mathrm{FOM} / \mathrm{PIR}-\mathrm{V}_{3}{ }^{*} / \mathrm{V}_{4}$ \\
\hline 9 & $\mathrm{PIR} / \mathrm{FOM} / \mathrm{PIR}-\mathrm{V}_{2} / \mathrm{V}_{3}{ }^{*} / \mathrm{V}_{4}$ \\
\hline 10 & $\mathrm{PIR} / \mathrm{PIR} / \mathrm{FOM} / \mathrm{PIR}-\mathrm{V}_{2} / \mathrm{V}_{3} / \mathrm{V}_{3}{ }^{*} / \mathrm{V}_{4}$ \\
\hline
\end{tabular}

The commercial product used with the active ingredient fomesafen was $\mathrm{Flex}^{\circledR}$, recommended for postemergence application of common bean, between stages V2 and V4 at doses of 0.9 to $1.0 \mathrm{~L} \mathrm{ha}^{-1}$ of c.p. (225 to $250 \mathrm{~g} \mathrm{ha}^{-1}$ of a.i.), the highest recommended dose was used for the experiment. In relation to the fungicide, the commercial product Comet $^{\circledR}$ was used, having as active ingredient pyraclostrobin, recommended from the appearance of the fourth bean trifolium, or in the first symptoms of the diseases in the culture, using a dose of $0.3 \mathrm{~L}$ ha-1 from c.p. (75 $\mathrm{g} \mathrm{ha}^{-1}$ of a.i.), the same dose used in the experiment. These pesticides were chosen because they had only the desirable active ingredients. In the herbicide treatments the Agral $^{\circledR}$ adjuvant was used at a dose of $0.5 \% \mathrm{vv}^{-1}$.

The first application of the treatments occurred when the plants were in V2 stage (10 days after sowing - DAS), where more than $50 \%$ of the plants had two primary leaves, the second application was carried out in V3 (23 DAS), where more than $50 \%$ of the plants had the first fully expanded trifolium and the last application in the V4 stage (29 DAS), where more than $50 \%$ of the plants already had the third fully expanded trifolium, according to Fernandez et al. (1982).

For the application of the treatments was used $\mathrm{a} \mathrm{CO}_{2}$ pressurized sprayer with a working pressure of $275 \mathrm{kPa}$, equipped with a $2.0 \mathrm{~m}$ bar, containing four spray tips type AVI 11002, flat jet, spaced in $0.5 \mathrm{~m}$ displacement speed of $1.0 \mathrm{~m} \mathrm{~s}^{-1}$, using application rate equivalent to $200 \mathrm{~L} \mathrm{ha}^{-1}$.

Phytotoxicity evaluations were initially performed at 7, 15 and 30 days after application of the treatments in V3 $\left(D A A V_{3}\right)$. For this evaluation scores were attributed from 0 to $100 \%$, where 0 represents no poisoning damage and 100 death of all plants (SBCPD 1995).

The evaluation of gas exchange was performed at $06 \mathrm{DAAV}_{3}$. Spot measurements were performed on the central leaflet of the last fully expanded trifolium, with simulated light intensity in the range of $1200 \mu \mathrm{mol} \mathrm{m}^{-2} \mathrm{~s}^{-1}$. A portable photosynthesis apparatus, the Infra-Red Gas Analyzer (IRGA, Li-6400, Licor Ltda., Lincoln, NE) was used. 
The gas exchange measurements were performed in the morning between 9:00 am and 11:00 am, where the values of $\mathrm{CO}_{2}(\mathrm{~A})$ assimilation, stomatal conductance (Gs), $\mathrm{CO}_{2}$ internal concentration (Ci), transpiration (E) and water use efficiency (WUE).

At the end of the bean cycle the desiccation of the culture was carried out with the application of paraquat $400 \mathrm{~g}$ ha $^{-1}$ (Gramoxone $200^{\circledR}$ ) with the Agral $^{\circledR}$ adjuvant $\left(0.2 \% \mathrm{v} \mathrm{v}^{-1}\right)$ in total area. After grace period of herbicide, manual harvesting of the plot area was realized.

The stand and number of pods per plant were evaluated at the end of the cycle and after harvesting it was determined the mass of 1,000 grains and productivity, with moisture correction to $130 \mathrm{~g} \mathrm{~kg}^{-1}$.

The data were submitted to analysis of variance by the $\mathrm{F}$ test and the means were compared by the Scott-Knott group test, both at $5 \%$ probability. Statistical analysis was performed using the SISVAR statistical software.

\section{RESULTS AND DISCUSSION}

In general, there was a low intensity of injuries after the treatments. The symptoms were characterized by mild chlorosis in the trefoil bean plants. A significant difference was observed only in the first evaluation (7 DAAV 3 ), where the use of fomesafen and pyraclostrobin (V3) by tank mix and the three applications of pyraclostrobin (V2, V3 and V4) and one of fomesafen (V3) resulted in higher phytotoxicity, with 9.75 and $11.25 \%$, respectively (Table 2). The other treatments presented symptoms of phytotoxification with intensity varying from 4 to $7 \%$, being superior to the control. In the subsequent evaluations, the phytotoxication symptoms were reduced, and at 30 $\mathrm{DAAV}_{3}$ no more symptoms were seen in any of the treatments (data not shown), indicating the complete recovery of the injuries observed in the first evaluation. This is due to the low mobility of fomesafen, which is typical of Protox inhibitors (Silva et al., 2018), where trefoils emitted after the application show no symptoms of intoxication.

Table 2. Percentage of phytointoxication of IPR Tangará bean plants treated with fomesafen e pyraclostrobin at 7 e 15 days after application of $V_{3}$ treatments $\left(D_{A A} V_{3}\right)$.

\begin{tabular}{lcc}
\hline \multirow{2}{*}{ Treatments } & \multicolumn{2}{c}{ Phytointoxication (\%) } \\
\cline { 2 - 3 } & 7 DAAV3 & 15 DAAV3 \\
\hline Control & $0.00 \mathrm{a}$ & $0.00^{\mathrm{ns}}$ \\
Fomesafen (FOM) $-\mathrm{V}_{3}{ }^{*}$ & $7.00 \mathrm{~b}$ & 0.75 \\
Pyraclostrobin $(\mathrm{PIR})-\mathrm{V}_{3}$ & $4.50 \mathrm{~b}$ & 1.25 \\
$\mathrm{PIR} / \mathrm{PIR}-\mathrm{V}_{2} / \mathrm{V}_{4}$ & $5.50 \mathrm{~b}$ & 0.50 \\
$\mathrm{PIR} / \mathrm{FOM}-\mathrm{V}_{2} / \mathrm{V}_{3}{ }^{*}$ & $4.00 \mathrm{~b}$ & 0.75 \\
$\mathrm{PIR}+\mathrm{FOM}-\mathrm{V}_{3}{ }^{*}$ & $9.75 \mathrm{c}$ & 1.75 \\
$\mathrm{PIR} / \mathrm{FOM}-\mathrm{V}_{3}{ }^{*}$ & $6.25 \mathrm{~b}$ & 0.50 \\
$\mathrm{FOM} / \mathrm{PIR}-\mathrm{V}_{3}{ }^{*} / \mathrm{V}_{4}$ & $5.25 \mathrm{~b}$ & 1.00 \\
$\mathrm{PIR} / \mathrm{FOM} / \mathrm{PIR}-\mathrm{V}_{2} / \mathrm{V}_{3}{ }^{*} / \mathrm{V}_{4}$ & $5.75 \mathrm{~b}$ & 1.00 \\
$\mathrm{PIR} / \mathrm{PIR} / \mathrm{FOM} / \mathrm{PIR}-\mathrm{V}_{2} / \mathrm{V}_{3} / \mathrm{V}_{3}{ }^{*} / \mathrm{V}_{4}$ & $11.25 \mathrm{c}$ & 1.00 \\
\hline $\mathrm{CV}(\%)$ & 31.00 & 125.86 \\
\hline / treatments application on different tanks. + treatment application on tank mix. \\
ns not significant at $5 \%$ probability.
\end{tabular}

Marchioretto et al. (2017) verified low phytotoxicity levels for common bean cultivars ANfc 9, IPR Uirapuru and BRS style at 14 DAA fomesafen $\left(250 \mathrm{~g} \mathrm{ha}^{-1}\right)$ at the V2 stage. The same was observed by Galon et al. (2018) for common bean IPR Tuiuiú with application of fluazifop-p-butyl $\left(250 \mathrm{~g} \mathrm{ha}^{-1}\right)+$ fomesafen $\left(250 \mathrm{~g} \mathrm{ha}^{-1}\right)$. The results also corroborate with Cieslik et al. (2014) who have recovered phytotoxicity symptoms in common bean plants, cultivars IPR Tiziu and IPR-81 at 21 fomesafen DAA.

Research by Mancuso et al. (2016) with cowpea bean cultivar BRS Guariba, found low levels of phytointoxication after the application of $250 \mathrm{~g} \mathrm{ha}^{-1}$ of fomesafen at the stage of eight to ten pairs of leaves. The highest phytotoxicity (17.0\%) was observed at 7 DAA, decreasing to 10.2 and $4.0 \%$, at 15 and 30 DAA, respectively. In another work using the same cowpea bean cultivar, the authors observed a percentage of phytotoxification of 34 and $40 \%$, at 14 and 28 DAA of $225 \mathrm{~g} \mathrm{ha}^{-1}$ of fomesafen at the V4-V5 stage, respectively, for this experiment (Fontes et al. 2013).

The low phytotoxicity observed in this work may be related to seed treatment, since one of the active ingredients of the commercial product used was pyraclostrobin, this fungicide remains active in the plant for a minimum period of 14 days according to the commercial product leaflet. Thus, even plants that did not receive pyraclostrobin after emergence had the physiological effect of pyraclostrobin from seed treatment, thus not suffering severe injuries from the application of fomesafen. 
Another factor that may have interfered in the low levels of phytointoxication is the climate of the region where the experiment was implanted. In the period of conduction of the experiment the conditions were optimal for the growth and development of the culture. The volume of precipitation was greater than $300 \mathrm{~mm}$, its distribution being homogeneous throughout the crop cycle. The daytime temperature rarely reached $30{ }^{\circ} \mathrm{C}$ and the nights had mild temperatures (Figure 1). These conditions are extremely favorable to liquid photosynthesis of plant $\mathrm{C} 3$, such as common bean, this favorable energy condition certainly contributed to the low intensity of symptoms and to the rapid recovery of plants.

Regarding the photosynthetic evaluations performed at the $6 \mathrm{DAAV}_{3}$, no significant difference between the treatments was observed (Table 3). Different from that observed by Manabe et al. (2014) that verified a reduction in the photosynthetic rate of common bean plants cultivar BSR Supremo after application of the commercial mixture of fluazifop-p-butyl + fomesafen $\left(180+225 \mathrm{~g} \mathrm{ha}^{-1}\right)$.

Table 3. Photosyntheticavaliations (net assimilation rate of carbon - $A\left(\mu \mathrm{mol} \mathrm{CO}_{2} \mathrm{~m}^{-2} \mathrm{~s}^{-1}\right)$, stomatal

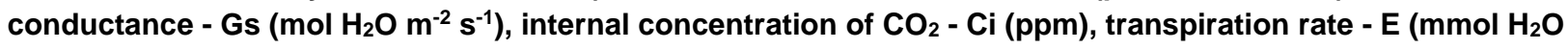
$\mathrm{m}^{-2} \mathrm{~s}^{-1}$ ) and photosynthetic efficiency in the use of water (WUE) of IPR Tangará bean plants at $06 \mathrm{DAAV}_{3}$.

\begin{tabular}{|c|c|c|c|c|c|}
\hline Treatments & $A$ & Gs & $\mathrm{Ci}$ & $E$ & WUE \\
\hline Control & $14.44^{\mathrm{ns}}$ & $0.46^{\mathrm{ns}}$ & $192.80^{\text {ns }}$ & $8.18^{\text {ns }}$ & $1.76^{\mathrm{ns}}$ \\
\hline Fomesafen $(\mathrm{FOM})-\mathrm{V}_{3}{ }^{*}$ & 16.23 & 0.46 & 178.28 & 8.16 & 1.99 \\
\hline Pyraclostrobin (PIR) $-V_{3}$ & 16.25 & 0.44 & 174.15 & 7.73 & 2.12 \\
\hline $\mathrm{PIR} / \mathrm{PIR}-\mathrm{V}_{2} / \mathrm{V}_{4}$ & 15.23 & 0.49 & 181.60 & 7.92 & 1.92 \\
\hline $\mathrm{PIR} / \mathrm{FOM}-\mathrm{V}_{2} / \mathrm{V}_{3}{ }^{*}$ & 15.18 & 0.47 & 180.81 & 7.62 & 1.98 \\
\hline $\mathrm{PIR}+\mathrm{FOM}-\mathrm{V}_{3}{ }^{*}$ & 15.37 & 0.49 & 178.40 & 8.49 & 1.80 \\
\hline $\mathrm{PIR} / \mathrm{FOM}-\mathrm{V}_{3}{ }^{*}$ & 15.48 & 0.44 & 169.16 & 8.11 & 1.91 \\
\hline $\mathrm{FOM} / \mathrm{PIR}-\mathrm{V}_{3}{ }^{*} / \mathrm{V}_{4}$ & 15.10 & 0.45 & 173.90 & 8.16 & 1.85 \\
\hline $\mathrm{PIR} / \mathrm{FOM} / \mathrm{PIR}-\mathrm{V}_{2} / \mathrm{V}_{3}{ }^{*} / \mathrm{V}_{4}$ & 14.08 & 0.39 & 168.17 & 7.84 & 1.77 \\
\hline $\mathrm{PIR} / \mathrm{PIR} / \mathrm{FOM} / \mathrm{PIR}-\mathrm{V}_{2} / \mathrm{V}_{3} / \mathrm{V}_{3}{ }^{*} / \mathrm{V}_{4}$ & 12.44 & 0.43 & 181.81 & 7.87 & 1.57 \\
\hline Mean & 14.98 & 0.45 & 177.91 & 8.01 & 1.87 \\
\hline CV (\%) & 12.83 & 12.33 & 5.26 & .82 & 11.45 \\
\hline
\end{tabular}

/ treatments application on diferent tanks. + treantment application on tank mix.

${ }^{\mathrm{ns}}$ not significant at $5 \%$ probability.

According to Takano et al. (2015), which used the same carioca bean cultivar and with the same dose of pyraclostrobin and fomesafen, when two applications of pyraclostrobin (V2 and V4) and one of fomesafen (V3) were performed, there was a significant increase in liquid assimilation of carbon in relation to the control at 7 DAA in contrast to the results obtained in this work. However, the mean net carbon assimilation rate observed by Takano et al. (2015) varied from $9.92 \mu \mathrm{mol} \mathrm{m}^{-2} \mathrm{~s}^{-1}$ on witness, to $10.01 \mathrm{e} 11.92 \mu \mathrm{mol} \mathrm{m}^{-2} \mathrm{~s}^{-1}$ on treatments with one (V2) and two applications (V2 and V4), respectively, presenting minor variations to those found in this work.

In the work performed by Takano et al. (2015) evaluated the rate of net carbon assimilation in post-emergence fungicide treatments of common bean, when using seed treatment and with the application of bentazon herbicide. These authors verified that when bentazon was applied in plants that received the seed treatment and in post emergence two applications of pyraclostrobin there was significant increase for this variable. When the seed treatment was not used, the reverse occurred. However, the rate of net assimilation of carbon did not exceed 14.03 $\mu \mathrm{mol} \mathrm{m} \mathrm{m}^{-2} \mathrm{~s}^{-1}$.

Increases in the photosynthetic rate of wheat, soybean and tomato plants after application of pyraclostrobin are also described in the literature (Grossmann et al. 1997; Fagan et al. 2010; Marek et al. 2018).

The increase in liquid photosynthesis is linked to changes in the $\mathrm{CO}_{2}$ compensation point, which favors $\mathrm{CO}_{2}$ uptake as opposed to release by respiration. This increase may be explained by the transient inhibition of respiration when the plant is treated with pyraclostrobin (Grossmann et al. 1997). According to Köehle et al. (2002), pyraclostrobin acts directly on the electron transport chain and also acts as a moderator of biotic and abiotic stresses because it participates in the metabolism of citric acid and stress hormones, such as abscisic acid. Thus, the decrease in respiration in plants treated with this fungicide may be an important factor, since it reduces the energy wastage of the plant to the maintenance metabolism.

However, for the present experiment no difference was observed in this variable. This probably occurred because the climatic conditions during the conduction of the experiment favored the development of the crop. The nights with mild temperatures are directly associated with reduced respiration, thus leading to lower energy losses (higher net photosynthetic rate) that would be required for maintenance of the plant. 
Daytime temperatures between 15 and $30^{\circ} \mathrm{C}$ may have contributed to the high rates of crude $\mathrm{CO} 2$ assimilation, and therefore no difference was observed with the application of pyraclostrobin, since the plants were exposed to optimal conditions for their development. What probably did not happen in the work of Takano et al. (2015), due to the region (North Central Paranaense, Maringá-PR, Brazil) and the time of conduction of the experiment (February to July), which resulted in bean plants developing in less favorable environmental conditions than those observed in Curitibanos-SC.

For the yield components: stand, number of pods per plant and mass of 1000 grains, there was no significant difference between the treatments (Table 4).

Table 4. Productivity components (stand. number of pods per plant and mass of 1000 grains) and productivity of IPR Tangará bean plants treated with fomesafen and pyraclostrobin.

\begin{tabular}{lcccc}
\hline Treatments & Stand & $\begin{array}{c}\text { No of } \\
\text { pods }\end{array}$ & $\begin{array}{c}\text { Mass of } \\
1000 \text { grains }(\mathrm{g})\end{array}$ & $\begin{array}{c}\text { Productivity } \\
\left(\mathrm{kg} \mathrm{ha}^{-1}\right)\end{array}$ \\
\hline Control & $12.50^{\mathrm{ns}}$ & $8.50^{\mathrm{ns}}$ & $318.2^{\mathrm{ns}}$ & $2742.03 \mathrm{~b}$ \\
Fomesafen (FOM) $-\mathrm{V}_{3}{ }^{*}$ & 13.81 & 7.00 & 328.5 & $2198.07 \mathrm{~b}$ \\
Pyraclostrobin (PIR) $-\mathrm{V}_{3}$ & 12.98 & 7.55 & 328.5 & $3592.24 \mathrm{a}$ \\
$\mathrm{PIR} / \mathrm{PIR}-\mathrm{V}_{2} / \mathrm{V}_{4}$ & 12.80 & 6.95 & 324.2 & $3425.87 \mathrm{a}$ \\
$\mathrm{PIR} / \mathrm{FOM}-\mathrm{V}_{2} / \mathrm{V}_{3}{ }^{*}$ & 12.26 & 7.20 & 327.4 & $3571.95 \mathrm{a}$ \\
$\mathrm{PIR}+\mathrm{FOM}-\mathrm{V}_{3}{ }^{*}$ & 12.20 & 7.65 & 316.2 & $3480.76 \mathrm{a}$ \\
$\mathrm{PIR} / \mathrm{FOM}-\mathrm{V}_{3}{ }^{*}$ & 12.14 & 7.65 & 313.9 & $3498.70 \mathrm{a}$ \\
$\mathrm{FOM} / \mathrm{PIR}-\mathrm{V}_{3}{ }^{*} / \mathrm{V}_{4}$ & 10.89 & 8.10 & 320.9 & $3635.84 \mathrm{a}$ \\
$\mathrm{PIR} / \mathrm{FOM} / \mathrm{PIR}-\mathrm{V}_{2} / \mathrm{V}_{3}{ }^{*} / \mathrm{V}_{4}$ & 13.69 & 8.20 & 329.3 & $2593.22 \mathrm{~b}$ \\
$\mathrm{PIR} / \mathrm{PIR} / \mathrm{FOM} / \mathrm{PIR}-\mathrm{V}_{2} / \mathrm{V}_{3} / \mathrm{V}_{3}{ }^{*} / \mathrm{V}_{4}$ & 10.95 & 8.40 & 317.4 & $3272.01 \mathrm{a}$ \\
\hline Mean & 12.42 & 7.72 & 322.45 & - \\
\hline CV $(\%)$ & 13.84 & 14.33 & 2.85 & 16.98
\end{tabular}

Means followed by the same letter in the column do not differ by Scott-knott test. $p<0.05 \%$.

${ }^{n s}$ not significant at $5 \%$ probability.

For the variable productivity, a significant difference was observed, where the control $\left(2742.03 \mathrm{~kg} \mathrm{ha}^{-1}\right)$, treatment with fomesafen (V3) only $\left(2198.07 \mathrm{~kg} \mathrm{ha}^{-1}\right)$ and treatment with two applications of pyraclostrobin (V2 and V4) and one of fomesafen (V3) (2593.22 $\left.\mathrm{kg} \mathrm{ha}^{-1}\right)$, presented lower productivity than the others that ranged from 3272.01 to $3635.84 \mathrm{~kg} \mathrm{ha}^{-1}$. The treatments that did not receive the application of pyraclostrobin were grouped with the lowest levels of productivity. These results corroborate with those obtained by Takano et al. (2015), where there was reported the improvement in the productivity of the Tangará IPR with the use of pyraclostrobin in V2 and V4 compared to the application in $\mathrm{V} 3$, and without the treatment of the fungicide seed. When seed treatment was used, the increase productivity was similar than that found in this study.

It can be noted that when the fungicide pyraclostrobin is not applied, productivity is affected, even with favorable conditions for the development of the crop. A study by Kozlowski et al. (2009) shows that the highest productivity of the IPR Uirapuru bean cultivar was achieved when two applications of pyraclostrobin were carried out, according to the authors, the increase was due to the higher number of pods per plant. This situation was not repeated in the present research.

Takano et al. (2015) pointed out that regardless of the treatment of the seeds with pyraclostrobin, the common bean plants that received two applications of pyraclostrobin presented productivity similar or superior to the other treatments. However, when the productivity was compared only in the treatments where seed treatment was not performed, this increase was more evident. This is probably due to the effect of pyraclostrobin used in seed treatment, where it would have promoted a physiological effect on the initial development of common bean plants. With the results obtained it can be observed that the herbicide fomesafen caused minor injuries in the common bean crop, however, these did not directly influence the productivity. However, new work should be performed to clarify the physiological effect of pyraclostrobin in this crop, as it was noted a positive effect of pyraclostrobin applications on the productivity of common bean cultivar IPR Tangará.

\section{Acknowledgments}

The authors thank the National Council for Scientific and Technological Development of Brazil (CNPq) for the financial support for scientific initiation of the first author and the Federal University of Santa Catarina for the structure for the execution of the work.

\section{References}

Alves C et al. 2018. Effect of herbicides in the oxidative stress in crop winter species. Anais da Academia Brasileira de Ciências 90:1533-1542. 
Cury JP et al. 2011. Produção e partição de matéria seca de cultivares de feijão em competição com plantas daninhas. Planta Daninha 29:149158.

Embrapa. 2018. Centro Nacional de Pesquisas de Solos. Sistemas Brasileiro de Classificação de Solos. Brasília: Embrapa.

Fagan EB et al. 2010. Efeito da aplicação de piraclostrobina na taxa fotossintética, respiração, atividade da enzima nitrato redutase e produtividade de grãos de soja. Bragantia 69?:771-777.

Fernandez F et al. 1982. Etapas de desarollo de la planta de frijol comum. Cali: Centro Nacional de Agricultura Tropical. pp. 26.

Fontes JRA et al. 2013. Seletividade e eficácia de herbicidas para cultura do feijão-caupi. Revista Brasileira de Herbicidas 12:47-55.

Galon $L$ et al. 2016. Interference and economic threshold level for control of beggartick on bean cultivars. Planta Daninha 34:411-422.

Galon L et al. 2018. Weed management in beans using subdoses of fluazifop-p-butyl + fomesafen. Planta Daninha 36:e018174070.

Grossmann $\mathrm{K}$ et al. 1997. Bioregulatory effects of the fungicidal strobilurin kresoxim methyl in wheat Triticum aestivum L. Pesticide Science 50:11-20.

IAPAR. 2019. Principais características das cultivares de feijão com sementes disponíveis no mercado. Available at: http://www.iapar.br/pagina-1363.html. Acessed on Jun. 19, 2019.

Köehle $\mathrm{H}$ et al. 2002. Physiological effects of the strobilurin fungicide F 500 on plants. In: Modern fungicides and antifungal compounds III. Andover. p.61-74.

Köppen W. 1948. Climatologia: com um estudo de los climas de la tierra. Fundo de Cultura Economica: Mexico.

Kozlowski LA et al. 2002. Período crítico de interferência das plantas daninhas na cultura do feijoeiro-comum em sistema de semeadura direta. Planta Daninha 20:213-220.

Kozlowski LA et al. 2009. Efeito fisiológico de estrobilurina F500 no crescimento e rendimento do feijoeiro. Ciências Agrárias e Ambientais 7:41-54.

Linhares CMS et al. 2014. Crescimento do feijão-caupi sob efeito dos herbicidas fomesafen e bentazon + imazamox. Caatinga.27:41-43.

Machado FG et al. 2018. Development and grain quality of soybean cultivars treated with pyraclostrobin and biostimulant. Comunicata Scientiae 9:235-241.

Manabe PMS et al. 2014. Características fisiológicas do feijoeiro em competição com plantas daninhas. Bioscience Journal 30:1721-1728.

Mancuso MAC et al. 2016. Seletividade e eficiência de herbicidas no controle de plantas daninhas na cultura do feijão-caupi. Revista Ceres 63:025-032.

Marchioretto LR et al. 2017. Weed control and crop selectivity of post-emergence herbicides in common beans. Ciência Rural 47:1-6.

Marek $\mathrm{J}$ et al. 2018. Photoynthetic and productive increase in tomato plants treated with strobilutins and carboxamides for the control of Alternaria solani. Scientia Horticulturae 242:76-89.

Sbcpd. 1995. Procedimentos para instalação, avaliação e análise de experimentos com herbicidas. SBCPD: Londrina.

Silva LO et al. 2018. Doses de fomesafen no feijoeiro comum cultivado em diferentes densidades de semeadura. Agrogeoambiental 10:57-66.

Silva VP et al. 2013. Eficiência e residual no solo de herbicidas na cultura do feijão. Planta Daninha 31:961-970.

Takano HK et al. 2015. Redução da fitointoxicação por herbicidas aplicados no feijoeiro com a utilização de fungicidas. Revista Agrarian 27:1222. 